\title{
Growth rates of follicles in the ovary of the cow*
}

\author{
J. G. Lussier†ף, P. Matton† and J. J. Dufour $\ddagger \S$ \\ $\dagger$ Département de biologie, Faculté des sciences, Université de Sherbrooke, Sherbrooke, Québec, \\ Canada JIK $2 R 1$ and $\ddagger$ Station de recherches, Agriculture Canada, Lennoxville, Québec, \\ Canada J1M $1 Z 3$
}

\begin{abstract}
Summary. Follicular growth rates were studied in 5 Hereford-Holstein cross heifers on Day 14 of the oestrous cycle. The granulosa cell mitotic index (MI) was measured in non-atretic antral follicles of various diameters $(0.13-8.57 \mathrm{~mm})$ from Bouin-fixed ovaries collected before (199, control) and $2 \mathrm{~h}$ after colchicine treatment (189, treated). In control ovaries, follicles of $0.68-1.52 \mathrm{~mm}$ had a higher MI than those of other size classes $(P<0.05)$. In colchicine-treated ovaries, the MI of follicles ranging from 0.68 to $8.57 \mathrm{~mm}$ increased more than that of other sized follicles, so that the mitotic time was shorter $(0.78 \mathrm{~h} v s 1.32 \mathrm{~h})$ in medium and large sized follicles $(0.68-8.57 \mathrm{~mm})$ than in smaller follicles $(0.13-0.67 \mathrm{~mm})$. Calculations based on the number of granulosa cells in follicles of various classes and from the time required to double the number of cells within a follicle indicate that a follicle takes 27 days to grow from 0.13 to $0.67 \mathrm{~mm}, 6.8$ days from 0.68 to $3.67 \mathrm{~mm}$ and 7.8 days from 3.68 to $8.56 \mathrm{~mm}$, indicating that growth rates varied with the size of the follicle. A period equivalent to 2 oestrous cycles would therefore be required for a follicle to grow through the antral phase, i.e. from $0.13 \mathrm{~mm}$ to preovulatory size. Increased MI, decreased mitotic time and increased atresia found in follicles larger than $0.68 \mathrm{~mm}$ could indicate a change in the follicular metabolism during its maturation.
\end{abstract}

\section{Introduction}

Rates of follicular growth are known for several small mammals (Peters \& Levy, 1966; Pedersen, 1970; Oakberg \& Tyrell, 1975; Chiras \& Greenwald, 1977; Hirshfield, 1984) and for women (Gougeon, 1982). In large domestic animals, the follicular growth rate has been determined in sows by macroscopic observations (Dailey et al., 1976) and in three breeds of sheep by microscopic observations (Cahill \& Mauléon, 1980; Turnbull et al., 1977). In the cow, the studies of Dufour et al. (1972), Matton et al. (1981) and Pierson \& Ginther (1984) have provided pertinent information on the relative stability, replacement and growth rates of the larger follicles. Since these data were obtained with macroscopic observations, they give no information on small and medium-sized follicles. It has been suggested that growth of an antral follicle to the preovulatory stage in the cow requires 40 days (Marion \& Gier, 1971) or 10 days (Priedkalns et al., 1968). Scaramuzzi et al. (1980) used the figures obtained by Turnbull et al. (1977) on the duration of mitosis in sheep (25.8 $\mathrm{min})$ to estimate the rate of follicular growth in the cow. They reported that a follicle required 22 days to grow from 0.4 to $10 \mathrm{~mm}$ in diameter. However, the validity of these calculations is questionable,

\footnotetext{
${ }^{*}$ Reprint requests to Dr P. Matton.

$\uparrow$ Present address: Department of Veterinary Physiological Sciences, University of Saskatchewan, Saskatoon, Saskatchewan, Canada S7N 0W0. §resent address: Département de Zootechnie, Université Laval, Sainte-Foy, Québec, Canada G1K 7P4.
} 
since there is disagreement between the results of Turnbull et al. (1977) and those of Cahill \& Mauléon (1980) concerning the duration of mitosis.

Knowledge of follicular growth rate in the cow is important for several reasons. These include not only its relevance to basic comparative biology, but also a better understanding and control of superovulation in the cyclic cow, and of the beginning or resumption of ovarian activity associated with puberty or post-partum anoestrus. The aim of this study was to determine the growth rate of antral follicles in cyclic heifers, using the colchicine method. Colchicine is a stathmokinetic agent which blocks all cells at the metaphase stage of mitosis without affecting the entry of new cells into mitosis.

\section{Materials and Methods}

Preparation of ovaries. Five Hereford-Holstein cross heifers with known regular cycles were used. On Day 14 of the oestrous cycle, one ovary (control or T0) was removed through a vaginal incision. The animal was then immediately injected with an intravenous bolus of colchicine $(1 \mathrm{mg} / \mathrm{kg}$ body weight) dissolved in physiological saline $(9 \mathrm{~g} \mathrm{NaCl} / \mathrm{l})$. After $2 \mathrm{~h}$, the animal was killed and the second ovary (treated or T2 ovary) was removed immediately. Ovaries with and without the corpus luteum were taken alternately as control or treated ovaries. Upon removal, ovaries were perfused with Bouin's fixative through the ovarian artery or vein and immersed in that solution for 5 days. The ovaries were then dehydrated, embedded in paraffin wax and sectioned at a thickness of $7 \mu \mathrm{m} ; 1$ out of every 3 sections was mounted and stained with Harris' haematoxylin.

Measurements of follicles. The histological sections were studied under a projection microscope and all follicles larger than $0.13 \mathrm{~mm}$ in diameter were counted and drawn at their largest diameter as limited by the basement membrane. The cross-sectional areas of the granulosa and the antrum were measured with a planimeter. Follicles were classified by their size according to the classification of Mariana \& Huy (1973). When the granulosa layer had a reduced thickness, a loosened margin or contained several pycnotic nuclei, the follicle was considered atretic. Nonatretic follicles had intact and normal granulosa layers with a mean pycnotic index per class varying from $0 \cdot 13$ to $0.67 \%$.

Mitotic index of follicles and calculations. For each ovary, 8-10 non-atretic follicles per class with a diameter median to the class were chosen to evaluate the mitotic index. In class 6 , all non-atretic follicles $(6$ and 4 follicles in the 5 control and treated ovaries respectively) were used for determination of the mitotic index. Thus a total of 199 control and 189 treated follicles were studied. For each follicle, all granulosa cells in prophase and metaphase were counted on three consecutive sections of the follicle at its largest diameter. The mitotic index was calculated from the number of mitotic figures counted divided by the estimated total number of cells, calculated from the cross-sectional area $\left(\mathrm{mm}^{2}\right)$ times the mean cell density $\left(15655 \mathrm{cells} / \mathrm{mm}^{2}\right)$. Cellular density was measured by counting the granulosa cells of 6-8 follicles per class. Numbers of cells in the granulosa layer of follicles at the lower and upper limit of the class were estimated from the cross-sectional area of the granulosa and the cellular density. For each follicular class the equations of Puck \& Steffen (1963) were used to calculate (a) the duration of mitosis or mitotic time: $\mathrm{MT}=2 \times \log \left(1+\mathbf{M I}_{\mathrm{TO}}\right) / \log \left(1+\mathrm{MI}_{\mathrm{T} 2}\right)$ [where $\mathrm{MT}=$ mitotic time, $\mathbf{M I}_{\mathrm{T} 0}=$ mitotic index at $\mathrm{T} 0, \mathbf{M I}_{\mathrm{T} 2}=$ mitotic index at T2]; (b) the doubling time of the granulosa cells: DT $=0.301 \times \mathrm{MT} / \log \left(\mathrm{I}+\mathrm{MI}_{\mathrm{T} 0}\right)$ [where DT $=$ doubling time, MT = mitotic time for a given class]; and (c) the time in hours to pass through each class: CT $=$ DT [(log $\mathrm{N}-\log \mathrm{N} 0$ )/ 0.031 ] [where $\mathrm{CT}=$ time required to pass through a class, $\mathrm{N} 0$ and $\mathrm{N}$ are the number of cells at the lower and upper limit respectively of a given class]. The mitotic index for each follicle was analysed by least squares analysis of variance. Differences between treatment means were determined by Duncan's multiple range test (SAS, Inst. 1982).

\section{Results}

The average diameter of the 5 smallest follicles with a discrete antrum per ovary was $0 \cdot 14 \mathrm{~mm}$. All follicles larger than $0.29 \mathrm{~mm}$ had an antrum. Of the 1236 Class 2 follicles observed, $36 \%$ had a discrete antrum. Non-antral and antral follicles of Class 2 had an average diameter of $0 \cdot 17$ and $0.21 \mathrm{~mm}$ respectively. Very little difference was observed in the cellular density between follicles of various classes, although cellular density was slightly less in follicles of Class 4 (Table 1). Variation in cellular density decreased with increasing size of the follicle, from $5.6 \%$ in follicles of Class 2 to $2.0 \%$ in follicies of Class 6 . The mean cellular density of $15655 / \mathrm{mm}^{2}$ was therefore used for calculation of the mitotic index.

The relationship between granulosa cross-sectional area and follicular diameter is shown in Fig. 1 . Because only a few follicles with diameters similar to that of the upper and lower limits of Class 6 
Table 1. Characteristics of follicles from different size classes

\begin{tabular}{ccccc}
\hline Class* & $\begin{array}{c}\text { Cellular } \\
\text { density } \\
\left.\text { (cells/mm } / \mathrm{mm}^{2}\right)\end{array}$ & $\begin{array}{c}\text { Diameter } \\
(\mathrm{mm})\end{array}$ & $\begin{array}{c}\text { Cross-sectional area } \\
\text { of granulosa } \\
(\text { mean } \pm \text { s.e.m. })\left(\mathrm{mm}^{2}\right)\end{array}$ & $\begin{array}{c}\text { Estimated } \\
\text { no. of cells/ } \\
\text { section† }\end{array}$ \\
\hline 2 & 16391 & 0.130 & $0.0107 \pm 0.001$ & 168 \\
3 & 15803 & 0.285 & $0.047 \pm 0.002$ & 736 \\
4 & 14398 & 0.675 & $0.173 \pm 0.015$ & 2708 \\
5 & 16131 & 1.525 & $0.355 \pm 0.04$ & 5558 \\
6 & 16608 & 3.675 & $0.74 \ddagger$ & 11585 \\
\hline
\end{tabular}

*Follicles were classified by their size according to the classification of Mariana \& Huy (1973).

†Estimated number of cells/section $=$ cellular density $\left(\mathrm{cells} / \mathrm{mm}^{2}\right)$ times cross-sectional area $\left(\mathrm{mm}^{2}\right)$.

$\ddagger$ Value calculated from the equation of the granulosa area vs follicular diameter.

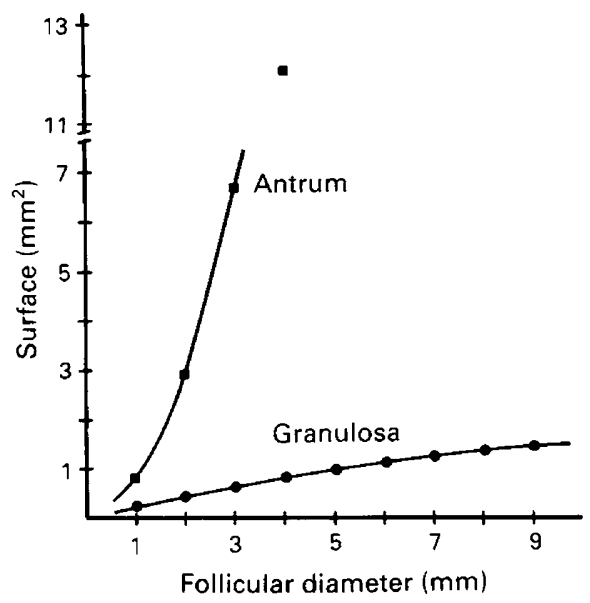

Fig. 1. Cross-sectional area of the granulosa $\left(\mathrm{mm}^{2}\right)$ and of the antrum $\left(\mathrm{mm}^{2}\right)$ in relation to the diameter $(\mathrm{mm})$ of the follicle. The equations for the granulosa $\left(y=0.2341 x-0.0077 x^{2}-\right.$ $0.0113)$ and for the antrum $\left(y=0.31676-0.30435 x+0.80778 x^{2}\right)$ were computed by least squares polynomial regression, goodness of fit applied on each degree.

were non-atretic, the area of the granulosa for follicles between 3.67 and $8.56 \mathrm{~mm}$ was estimated from the equation for the curve in Fig. 1 and was found to be 0.74 and $1.43 \mathrm{~mm}^{2}$ respectively (Table 1). The cross-sectional area of the antrum showed a rapid exponential increase with increasing diameter of the follicle (Fig. 1). Thus, while the granulosa area represented $27 \%$ of the follicular cross-section in follicles of $1 \mathrm{~mm}$ in diameter, it represented only 8.8 and $6.4 \%$ in follicles of 3 and $4 \mathrm{~mm}$ respectively.

Figure 2 shows the mitotic index in follicles from control and colchicine-treated ovaries. The coefficient of variation of the mitotic index between cows went from 12 to $26 \%$ for the different follicular classes. There was a significant difference in the index between different classes at T0, follicles of Class 4 showing the greatest mitotic activity $(P<0.001)$. After colchicine treatment, 


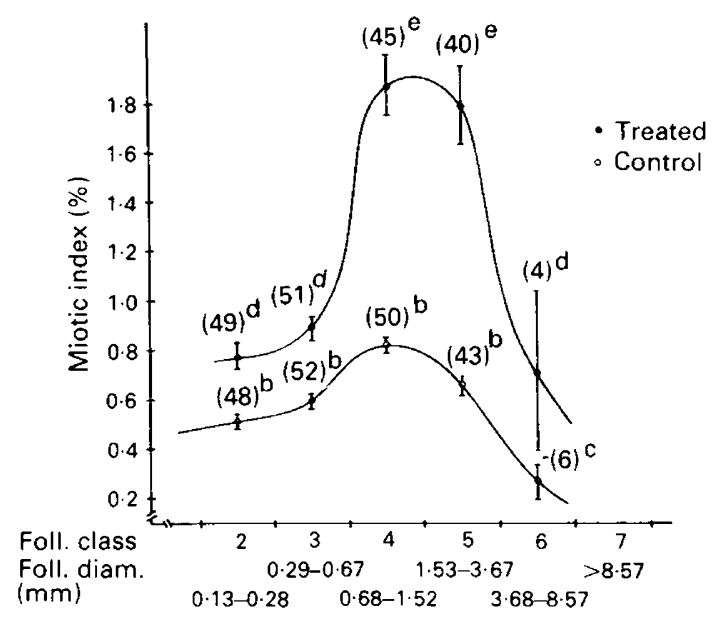

Fig. 2. Representation of the mean mitotic index ( \pm s.e.m.) per class for the untreated and colchicine-treated follicles. Values with different superscripts are significantly different $(P<0.05$ : ANOVA, Duncan's multiple range test).

Table 2. Mitotic time (MT), doubling time (DT) and time spent in each class (CT) of ovarian follicles of cows

\begin{tabular}{cccc}
\hline $\begin{array}{l}\text { Follicular } \\
\text { class }\end{array}$ & $\begin{array}{c}\text { MT } \\
\text { (h) }\end{array}$ & $\begin{array}{c}\text { DT } \\
\text { (h) }\end{array}$ & $\begin{array}{c}\text { CT } \\
\text { (h) (days) }\end{array}$ \\
\hline 2 & 1.32 & 172 & $365 \cdot 5(15 \cdot 1)$ \\
3 & 1.33 & 154 & $284.9(11.9)$ \\
4 & 0.89 & 77 & $99 \cdot 5(3.31)$ \\
5 & 0.70 & 78 & $83.2(3.47)$ \\
6 & $0 \cdot 76$ & 191 & Total $=997.3(71 \cdot 5)$ \\
& & & $997.5)$ \\
\hline
\end{tabular}

there was an increase in the mitotic index, with the increase being proportionally greater in follicles of Classes 4 and 5 (128 and $189 \%$ compared with 50 and $48 \%$ of Classes 2 and 3 ). No anaphase or telophase figures were observed in treated follicles compared with the non-treated follicles. The calculated duration of mitosis therefore differed in the various classes (Table 2). Similarly, the time required by a follicle to pass through each class was much less for Classes 4,5 and 6 than for Classes 2 and 3. The estimated time for a follicle to grow from 0.13 to $8.56 \mathrm{~mm}$ was 41.5 days, the equivalent of 2 oestrous cycles.

At Day 14 of the oestrous cycle, the total number of follicles per ovary $(\geqslant 0.13 \mathrm{~mm})$ varies amongst animals from 127 to 490 for both ovaries of a cow, although there are similar numbers of follicles for each follicular class (Fig. 3). The differences in the number of follicles between Cows $\mathrm{A}$ and $\mathrm{E}$ were high for Classes 2-5, but not for Class 6. Follicles of Classes 2 and 3 constituted $75 \%$ of the total follicular population studied (Fig. 4). Atresia was negligible in these classes in which atretic follicles represented only 1.6 and $6.6 \%$ of the follicular population, whereas atretic follicles represented $40.5,30$ and $67.4 \%$ in Classes 4,5 and 6 , respectively. There was a positive correlation between the mean number of follicles per class and the time required to pass through that class $(r=0.936, P<0.02$ ) for follicles between 0.13 and $3.67 \mathrm{~mm}$ in diameter. 


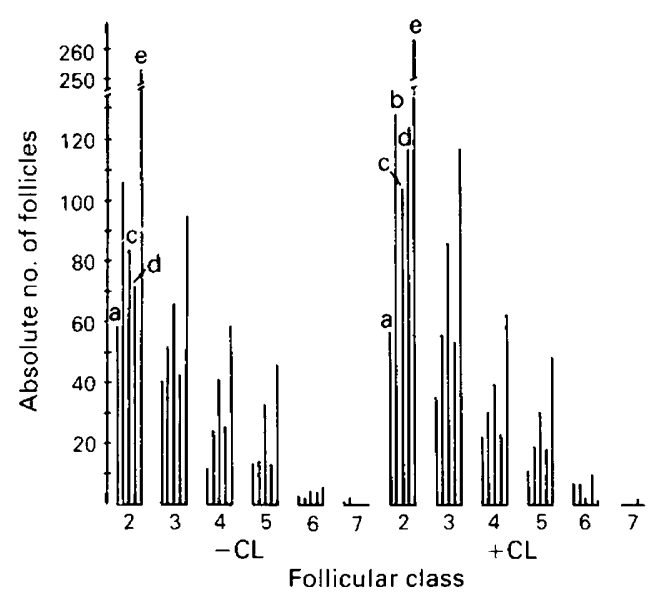

Fig. 3. Relationship between the absolute number of follicles per class and per ovary bearing $(+C L)$ or not bearing $(-C L)$ the corpus luteum. The letters $a, b, c, d$, e represent the different animals studied.

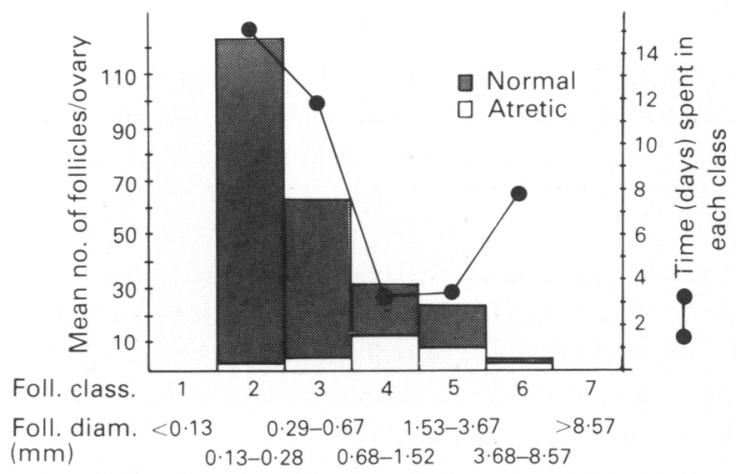

Fig. 4. Relationship between the mean number of normal and atretic follicles, the time spent in a follicular class and the follicular diameter.

\section{Discussion}

The present observations confirm those of other workers who reported that antrum formation starts in follicles ranging from 0.12 to $0.16 \mathrm{~mm}$ (Mariana \& Machado, 1976; Monniaux et al., 1984; Maurasse et al., 1985; Dufour \& Roy, 1985) but differ from those of Marion et al. (1968) and Marion \& Gier (1971) who observed a discrete antrum only in follicles with a diameter of about $0.7 \mathrm{~mm}$. Our results show also that the antrum can develop over a certain range of diameters $(0.14-0.28 \mathrm{~mm})$. From the present study, growth of the antral follicles can be divided into two phases. Firstly, early growth of follicles can be attributed to an increase in the number of granulosa cells and therefore an increase in the surface of the granulosa layer. Secondly, in follicles larger than $2.5 \mathrm{~mm}$, follicular growth appeared to result from antrum development rather than an increase of the number of granulosa cells. This exponential increase in the antrum surface is in agreement with the observations of Mariana \& Machado (1976).

The mitotic index for the different classes of follicles at time 0 shows a pattern similar to that reported for the cow by Scaramuzzi et al. (1980) and for the ewe by Turnbull et al. (1977) and Cahill \& Mauléon (1980). The ovaries of both species are therefore similar with respect to the absolute size 
at which the antrum is formed $(0 \cdot 13-0.20 \mathrm{~mm})$ and the follicular size at which the maximum mitotic activity is observed $(0.68-1.52 \mathrm{~mm})$.

The colchicine-induced increase in the mitotic index of follicles of Classes 4 and 5 was not proportional to the increase seen in follicles of Classes 2 and 3. These results differ from those of Cahill \& Mauléon (1980) who did not observe a clear difference between classes in the increase of mitotic index after colchicine due to the large variability in the index in treated ovaries. According to Cahill (1979), this variability is thought to result from the difference in growth rate among follicles selected to ovulate and those in the early process of atresia. The wide variation could also have resulted from the technique used by Cahill \& Mauleon (1980) to select the section analysed for diameter measurement (i.e. presence of the oocyte). Comparisons with other similar studies (Turnbull et al., 1977; Gougéon, 1982) are not possible since the mitotic index, after treatment with colchicine, was not reported for individual follicular classes. In the present study, the large difference between the mitotic index in control and treated follicles of Classes 4 and 5 , the low variability and the larger number of follicles studied suggest that this difference is not an artefact. The mitotic times ( $79 \cdot 2 \mathrm{~min}$ ) for granulosa cells of small follicles (Classes 2 and 3 ) were similar to those reported by Cahill \& Mauléon (1980) for sheep and by Gougéon (1982) for women, but unlike these reports, a shorter mitotic time $(49.8 \mathrm{~min})$ was found for larger follicles. Mamontov $e t$ al. (1980) also reported that the length of mitosis decreases with increasing rate of mitotic activity.

Oestrogens are known to stimulate mitotic division in granulosa cells (Harman et al., 1975; Richards, 1979). Our results could be interpreted to suggest that there is a marked increase of oestradiol production in follicles larger than $0.68 \mathrm{~mm}$ and also that oestradiol could reduce the mitotic time of granulosa cells. Cahill \& Mauléon (1980), Scaramuzzi et al. (1980) and Gougéon (1982) have used the addition of the times required by a follicle to pass through each class to estimate the time required by a follicle to grow from antrum formation to preovulatory size. Such calculations assume that there are no diurnal rhythms in cell proliferation or no differences in the rate of cell proliferation at different times of the oestrous cycle. Hirshfield (1984) has reported a diurnal variation in the mitotic index of rat granulosa cells. Although diurnal variations cannot be excluded in cows because there is no available information, it is likely that they have a much less marked effect in cows than in rodents since antral follicular growth appears to take a much longer time in cows (several weeks compared to 1-2 days in rodents). In sheep, Cahill \& Mauléon (1980) have shown that follicular growth rate was similar at Day 0 and 7 of the cycle. The present results show that the curve obtained by plotting the mitotic indices of the various sizes of follicles of Day 14 of the cycle is similar to that reported by Scaramuzzi et al. (1980) for follicles obtained after luteolysis with PGF-2 $\alpha$. This suggests that the variation in the growth rates of the follicles of various sizes would be similar during the luteal phase (Day 14) and the follicular phase (after luteolysis). Addition of the time of passage through the different classes shows that, in the cow, 42 days or two cycles would be required for a follicle to grow through the antral stage, i.e. from 0.13 to $8.56 \mathrm{~mm}$. Scaramuzzi et al. (1980) reported a value of 22 days for a follicle to grow from 0.4 to $10 \mathrm{~mm}$. These authors, however, used as a basis for their calculation the mitotic time of $25.8 \mathrm{~min}$ obtained in sheep by Turnbull et al. (1977). Our results for cows show that the mitotic time is almost twice as long as in follicles larger than $0.68 \mathrm{~mm}$ and even longer in small follicles.

Estimation, however, of the time required for large follicles to grow from 3.68 to $8.56 \mathrm{~mm}$ (7.8 days) should be taken with caution since there is a marked variation in the mitotic index of granulosa cells of large follicles (Fig. 2). This variation could mean that growth rate varies markedly between different follicles or that fast growth of the large follicle can result from the rapid expansion of the antrum without concomittant granulosa expansion requiring cell division. Furthermore, previous reports using follicular marking and cauterization (Dufour et al., 1972; Matton et al., 1981), or sonography (Pierson \& Ginther, 1984) suggest a differential growth rate for the large follicles during the luteal phase compared to the follicular phase.

During the development of antral follicles, Class $4(0.68-1.52 \mathrm{~mm})$ appears to be a special stage with a change in characteristics. A slightly lower cellular density and a rapid increase of antrum size 
suggests cellular rearrangement. The increase in mitotic index and decreased mitotic time results in increased growth rate. Finally, there is a drastic increase in the percentage of atretic follicles.

In conclusion, the ovaries of cows appear to be similar to those of sheep regarding the size at which the antrum is formed and the follicular size at which maximum mitotic activity is observed. About 2 oestrous cycles would be required for a follicle to grow from antrum formation to preovulatory size. Follicular growth is slow in the small antral follicles but increases in follicles of $0.68-3.67 \mathrm{~mm}$. This increase results not only from an increase in the mitotic index but also from a decrease in the duration of mitosis. A drastic increase in the percentage of atretic follicles is associated with an increased follicular growth rate and follicular diameter.

This study was supported by research grants from Ministère de l'Agriculture, des Pêcheries et de l'Alimentation de la Province de Québec. We thank Mrs Micheline Doré-Roy for assistance with the preparation of the histological slides.

\section{References}

Cahill, L.P. (1979) Etudes de la folliculogénèse chez le mouton. Thèse de doctorat d'état ès Sciences naturelles, Université de Paris VI.

Cahill, L.P. \& Mauléon, P. (1980) Influences of season, cycle and breed on follicular growth rates in sheep. $J$. Reprod. Fert. 58, 321-328.

Chiras, D.D. \& Greenwald, G.S. (1977) An autoradiographic study of long-term follicular development in the cyclic hamster. Anat. Rec. 188, 331-338.

Dailey, R.A., Clark, J.R., Staigmiller, R.B., First, N.L., Chapman, A.B. \& Casida, L.E. (1976) Growth of new follicles following electrocautery in four genetic groups of swine. J. Anim. Sci. 43, 175-183.

Dufour, J.J. \& Roy, G.L. (1985) Distribution of ovarian follicular populations in the dairy cow within 35 days after parturition. J. Reprod. Fert. 73, 229-235.

Dufour, J.J., Whitmore, H.L., Ginther, O.J. \& Casida, L.E. (1972) Identification of the ovulating follicle by its size on different days of the estrous cycle in heifers. J. Anim. Sci. 34, 85-87.

Gougéon, A. (1982) Rate of follicular growth in the human ovary. In Follicular Maturation and Ovulation, pp. 155-163. Eds R. Rolland, E. V. Van Hall, S. G. Hillier, K. P. McNatty \& J. Shoemaker. Excerpta Medica, Amsterdam.

Harman, S.M., Louvet, J.P. \& Ross, G.T. (1975) Interaction of estrogen and gonadotrophins on follicular atresia. Endocrinology 96, 1145-1152.

Hirshfield, A.N. (1984) Stathmokinetic analysis of granulosa cell proliferation in antral follicles of cyclic rats. Biol. Reprod. 31, 52-58.

Mamontov, S.G., Ivanova, L.N. \& Zakharov, V.B. (1980) The 24 hour rhythm of mitoses and the rate of cell renewal in tissues of rats after adrenalectomy. Tsitologia 22, 168-175.

Mariana, J.-C. \& Huy, N. (1973) Folliculogénèse chez la vache. Annls Biol. anim. Biochim. Biophys. 13, 211-221.

Mariana, J.-C. \& Machado, J. (1976) Etude de la formation de l'antrum dans les follicules de l'ovaire de ratte et de vache normales ou stimulées par PMSG. Annls Biol. anim. Biochim. Biophys. 16, 545-559.

Marion, G.B. \& Gier, H.T. (1971) Ovarian and uterine embryogenesis and morphology of the non-pregnant female mammal. J. Anim. Sci. 32 (Suppl. 1), $24-47$.
Marion, G.B., Gier, H.T. \& Choudary, J.B. (1968) Micromorphology of the bovine ovarian follicular system. J. Anim. Sci. 27, 51-465.

Matton, P., Adelakoun, V., Couture, Y. \& Dufour, J.J. (1981) Growth and replacement of the bovine ovarian follicles during the estrous cycle. J. Anim. Sci. 52, $813-820$.

Maurasse, C., Matton, P. \& Dufour, J.J. (1985) Ovarian follicular populations at two stages of an estrous cycle in heifers fed a high or a low plane of nutrition. J. Anim. Sci. 61, 1194-1210.

Monniaux, D., Mariana, J.C. \& Gibson, W.R. (1984) Action of PMSG on follicular populations in heifers. J. Reprod. Fert. 70, 243-253.

Oakberg, E.F. \& Tyrell, P.D. (1975) Labelling the zona pellucida of the mouse oocyte. Biol. Reprod. 12, $477-482$.

Pedersen, T. (1970) Follicle kinetics in the ovary of the cyclic mouse. Acta endocr., Copenh. 64, 304-323.

Peters, H. \& Levy, E. (1966) Cell dynamics of the ovarian cycle. J. Reprod. Fert. 11, 227-236.

Pierson, R.A. \& Ginther, O.J. (1984) Ultrasonography of the bovine ovary. Theriogenology 21, $495-504$.

Priedkalns, J., Weber, A.F. \& Zemjanis, R. (1968) Qualitative and quantitative morphological studies of the cells of the membrana granulosa, theca interna and corpus luteum of the bovine ovary. Z. Zellforsch. mikrosk. Anat. 85, 501-520.

Puck, T.T. \& Stefien, J. (1963) Life cycle analysis of mammalian cells. I. A method for localizing metabolic events within the life cycle and its application to the action of colcemide and sublethal doses of $\mathrm{X}$ irradiation. Biophys. J. 3, 379-397.

Richards, J.S. (1979) Hormonal control of ovarian follicular development: a 1978 perspective. Recent Progr. Horm. Res. 35, 343-373.

SAS Institute Inc. (1982) SAS User's Guide Statistics. 1982 edn, SAS Institute, Inc., Cary, N.C., p. 584.

Scaramuzzi, R.J., Turnbull, K.E. \& Nancarrow, C.D. (1980) Growth of Graafian follicles in cows following luteolysis induced by the prostaglandin $F 2 \alpha$ analog, closprostenol. Aust. J. biol. Sci. 33, 63-69.

Turnbull, K.E., Braden, A.W.H. \& Mattner, P.E. (1977) The pattern of follicular growth and atresia in the ovine ovary. Aust. J. biol. Sci. 30, 229-241.

Received 4 November 1986 